\title{
イエメン・サナア旧市街保全の INTERNATIONAL TECHNICAL 国際技術協力 \\ ーワーディ・サーイラー整備計画一 \\ ASSISTANCE FOR THE \\ PRESERVATION OF THE OLD CITY OF \\ SANA'A, YEMEN \\ Case of the Wadi al-Sa'ilah improvement project
}

吉田正二 — $* 1$

キーワード :

世界遭産，サナア旧市街，保全，ワーディ整備計画，国際協力

Keywords :

World heritage, Old city of Sana'a, Conservation, Wadi al-Sa'ilah improvement project, International assistance

\author{
Masaji YOSHIDA $-* 1$
}

This paper refers to the Wadi al-Sa'ilah improvement project, which is one of the most important projects of the preservation plan for the Old City of Sana' a, Yemen. Before the establishment of the preservation office, the Ministry of Housing and Urban Planning made two plans. One of them is Open Channel Plan, which Yemen government adopted as their basic idea. This paper aims to give consideration to technical cooperation in conservation field through the examination of the various issues of the Yemeni Plan, revised version of the Open Channel Plan.

\section{1.はじめに}

イエメン共和国の首都サナアの旧市街はシバ王国の一都市として 繁栄した歴史を持ち，7 世紀以降はイスラーム都市としての特徽が 形成され，中世期の姿は今日までよく保存䧴持されている。

植民地化の経臨を持たないイエメンは 1962 年の革命以後に開発 の時期を迎え，サナア旧市街も 1970 年代後半より市壁や市門の一 部が徐々に取り除かれ变容している。しかしその一方でイエメン政 府はUNESCO（国際連合教育科学文化機閤）の協力を得て歴史的 建造物の調查を開始し，旧市街内建造物の保存に乗り出した。1984 年には政府は首相を議長とする「サナア旧市街保全委員会」を吐足

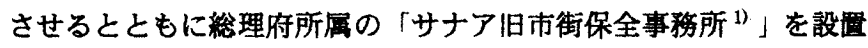
し保全事業実施に向けた準碏を進めた。その後 UNESCOはサナア 旧市街全体を一つの文化遗産として捉兑，この保全を世界にアピー ルすると共に 1986 年に世界遗産に登録した。

保全事務所は「サナア旧市街保全計画」全 59 項目を提示し，そ れに従い国侮的協力を得て事業を進めている2)。諸外国は尃門家の 派遗や资金援助を行い単体の歴史的建造物保存関係事業やインフラ ストラクチャー関你事業に協力している。

本稿は現地保全事務所で業務活動を通じて得た情報・資料に基 づき ${ }^{3)}$ ，サナア旧市街保全計画の一つである「ワーディは・・サーイ ラー整備計画」を取りあげ，国際技術協力の現状之課题を考察する。

\section{2. ワーディ・サーイラーの状況}

\section{2-1 位量}

サナア市全域におけるワーディ・サーイラー（Wadi al-Sa'llah, 以後ワーディと記すこともある。）は市域東端山岳部の尾根に平行 した形で南から北に延びている。その長さは上流の大統領官邱付近 から下流のサナア空港付近まで, 10 数 $\mathrm{km}$ に及んでいる（図 1)。

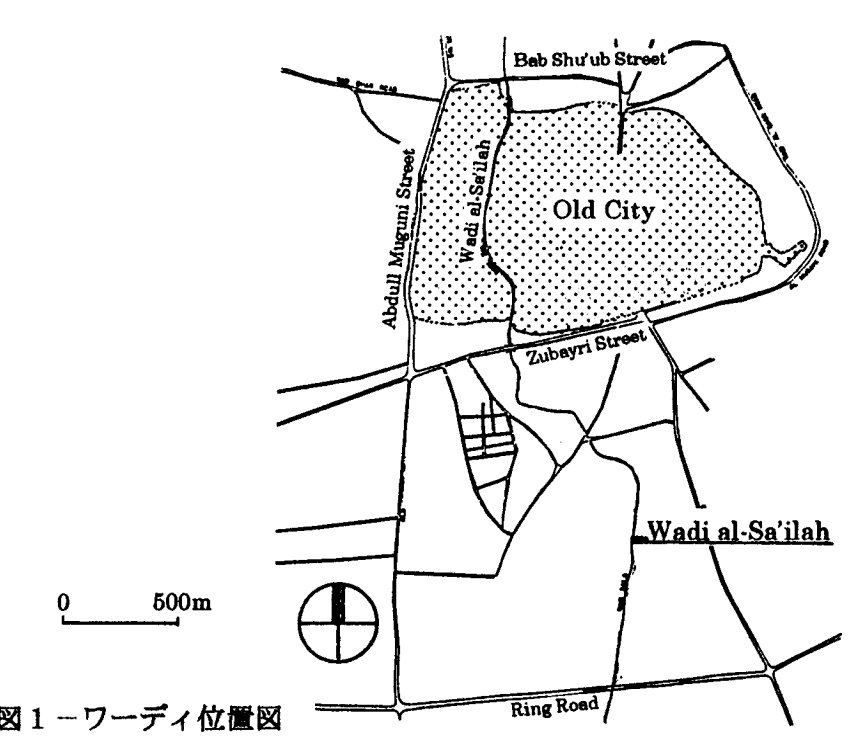

\section{2-2期之雨期}

ワーディは現在に至るまで年間 2 回の雨期には事実上の河川と化 すが，鞋期には自然の交通路として利用されてきた。今日車道とし て利用されるのは旧市街のみではなく，上流では南のリングロード を挟んだ約 $2 \mathrm{~km}$ ，北ではシュウーブ通りからさらに北のリングロー ドに至る約 $1.5 \mathrm{~km}$ の距離も利用されている。このような状況はワー ディと平行して走る旧市街西端境界のアブドゥル・ムグ二通りが市 を南北に結ぶ主要な道路の一つであり，通勤時，退社時だけでなく

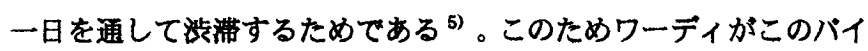
パス的役割を果たしている。特に旧市街部分では旧市街内生活者や 関你者の車檕以上の通過車㬏が多くなっている。

年 2 回の雨期は気象庁の過去の䓵緑を見る限り定期的なものでは 
ないが，年間月別降雨量の平均数值からみると 3 月から 5 月と 8 月 に雨が多いことがわかる（表 1）。しかしイエメン気像庁のサナア の雨量钼测地は市の西方にある上，サナアでは局地的雨が多いこと もあり，降雨量がワーディの水量に常に関わるとは限らない。

表 1 一年間月别降水量

\begin{tabular}{|c|c|c|c|c|c|c|c|c|c|c|c|c|c|}
\hline Mont & $\mathrm{jen}$ & $\mathrm{Fel}$ & Mar. & Apr. & $\mathrm{May}$ & tine & $\mu d x$ & Aun & Sep & Oct & No & Dec & tat \\
\hline$\left[\begin{array}{cc}83 & \text { Totad } \\
\text { Mox, 24t }\end{array}\right.$ & $\begin{array}{l}33.4 \\
27.4\end{array}$ & 13. & 125.9 & 89.5 & $\begin{array}{r}12.5 \\
4.6\end{array}$ & 0.0 & $\begin{array}{l}8.0 \\
80\end{array}$ & 70.9 & 0.0 & 0.0 & 0.0 & 0.0 & 353 \\
\hline 184 Totat & 0.0 & 0. & 2.0 & 10.2 & 39.8 & 13.0 & 0.0 & $\frac{5.9}{0.0}$ & 0.0 & 0.0 & 0.0 & 17.8 & 82.8 \\
\hline Ma. 245 & 0.0 & 0 & 0 & 8.8 & 4 & 13.0 & 0.0 & 0 & 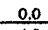 & 0 & 0 & 17.8 & \\
\hline & 0.0 & 0. & & 112.0 & 49.4 & 0.0 & 10.2 & 8.9 & 9 & 0 & 0.0 & 0.0 & 186.2 \\
\hline & 0.0 & 0. & & 30.9 & 43.1 & 0.0 & 10.2 & & & & & & \\
\hline 86 Total & 0.0 & 1. & 45.8 & 60.8 & 4.0 & 23.6 & 8.1 & 63 & 2.1 & 0.0 & 0.0 & 3.4 & 212.8 \\
\hline$M \times 24$ & & & & & 4 & 5 & 2.4 & & & & & 3.4 & \\
\hline & & & & & 19.4 & & 0.0 & 21,3 & & & 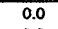 & 13.8 & 117.9 \\
\hline 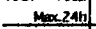 & 0 & 2. & 5 & 5.7 & 9.0 & 18.5 & 0.0 & 6.7 & 18.2 & 0.0 & 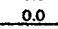 & 8.8 & \\
\hline and & 0.0 & 37 & 1.2 & $\begin{array}{l}67.4 \\
19.0\end{array}$ & 0.0 & $\begin{array}{l}0.0 \\
0.0\end{array}$ & $\begin{array}{l}73.2 \\
32.0\end{array}$ & $\begin{array}{r}20.7 \\
7.6\end{array}$ & 4.6 & 0.0 & 0.0 & $\begin{array}{l}0.0 \\
0.0\end{array}$ & 204.5 \\
\hline & 0.0 & & & 10 & 9 & 1.0 & 32.0 & 7.6 & & & 0.0 & 0.0 & \\
\hline & 5.6 & 9.1 & 30.3 & 59.2 & 9 & 9.3 & 16.6 & 30.9 & 5.4 & 0.0 & 0.0 & 5.8 & 93 \\
\hline
\end{tabular}

\section{2-3 旧市街におけるワーディ}

都市形成過程から見ると本来旧市街は 12 世紀頃まで現ワーディ 位置を西端としていた。その後西方に市街地が应張されたことで旧 市街内にワーディを取り込むことになった。この時ワーディに橋が 一つ架けられ，現存する。また，革命以前までワーディと市壁交差 部分には南北 2 䇴所で檽状構築物ハンダックが建設され，防衙上の 監視塔も備わっていた。

近代化により道路網の整硆が行われ，ハンダックは撒去された。 旧市街南北市壁と平行に建設されたアスファルト道路は，南のズバ イリー通りではワーディ上部にコンクリートの橋が架けられ，北の シュウーブ通りではワーディ交差部分の川休がコンクリート仕上げ された。旧市街部分を㭬切るワーディの距離は 2 道路間で約 $1.3 \mathrm{~km}$ である。

1988 年の測量図を見るとズバイリー橋のコンクリート橋脚部で 標高 $2247.02 \mathrm{~m}$ ，シュウーブ通り川休部で $2244.22 \mathrm{~m}$ であり，その 差は $2.8 \mathrm{~m}$ である。途中の区間の高さは雨期の侵食等により㚆動し ているが，全体的に楥やかな勾配を保っている。

ワーディの川床や法面は自然の状熊で放置され整備されないまま である。ワーディに面した住宅では下水管の不備や施工不良により 生活排水が漏水している。雨期には法面は自然に侵食・崩垻し続け ている。乾期には四輸鄅野車が砂煙をあけて走り拔ける。さらにこ こは旧市街において線上の大空間を占め両岸の景覥と関わる。この ようにワーディの存在は旧市街の雨水・排水問題, 交通問題, 生活 環境問題，景観問題などに大きく関わっている。

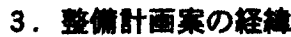

ワーディ整備計画は実施案に至るまで 4 案が，いずれも国際協力 を得て提示されている。これらは大きく2つに分けられる。一つは 保全事務所設立以前に都市住宅省によって道路整備の一瑟として考

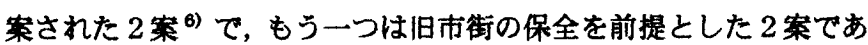
る。以下に各案の概要と一部背景を示す。

初期の 2 案は 70 年代後半から 80 年代前半に考案された。

(1)オープンチャンネル寨 : イギリスのコンサルタントによるこの案 は現在のワーディの現状を大幅に変えず，川床を平滑な切石で舗装 することにより流水と交通の両用にあて，法面を割石で石垣状に整 形するもので，旧市街のみを対象にする。

(2)ボックスカルバート案 : 中国の建設会社によるこの案は川床下に
鉄筋コンクリート造ボックスカルバートを設け，カルバートの上に 中央分離带を伴う自勳車道を建設するものである（図 2）。その長 さは旧市街南方から空港付近までの約 $7 \mathrm{~km}$ である。

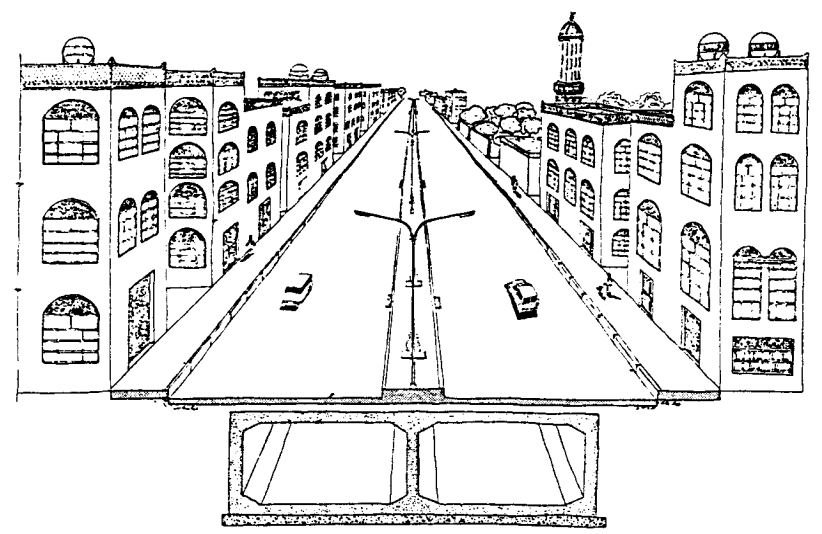

図 2 一計画案断面透視図（出典: 都市住宅省提供资料）

以後の 2 案はサナア旧市街保全計画の一事業として提案された。 (3)イタリア案: イタリア・コンサルタントはボックスカルバート案 を推咨しながらもこの案では旧市街の歴史的景覾を損なうものとし て批判し，ホックスカルパートを川床上ではなく川床下に設け，修 正ボックスカルバート案として提示した。川床は切石で舗装し自動 車道とし，法面は割石で装い，両岸を歩道として整備する内容であ る。しかしこの案はイタリア・コンサルタントの郮査不備によるボ ックスカルバートの位圈の桯解から生じたもので基本的に(2)と变わ らない7)。都市住宅省の案（困 2) には法面がなく, 再岸の住宅か 車道（河床部）と同レベルであることが誤解の原因と考えられる。 尚，同報告書には経淧的理由によりイタリア案が不可能ならばオ一 プンチャンネル案を採用しても良いと記されている。

この後イエメン政府は1986年，日本政府に「サナア旧市街保全」 のための技術協力を要請し，翌年日本政府は国際協力事業団(JCA) を通して 2 名の建築・土木の専門家を派寈した。この時に次の案が 提案された ${ }^{8)}$ 。

(4)川床下トンネル染 : 派遭専門家が提示した理想案は, 川床下に自 動車専用トンネルを設け, ワーディは自然の形状で残し，歩行者や 住民のためのオープンスペースとして整作するものである。

1988 年以後, イエメンではワーディ整備計画が最重要且つ緊急 を要する課通として浮上し，保全事務所の計画部に置いて実施案の 作成が急がれた。その頃，建設省及び財団法人国際建設技術協会は 海外建設計画情報収集調查のために 3 名からなる調查団をサナアに 派遗し，ワーディ整備計画の事前調查を実施した。報告書では(1)

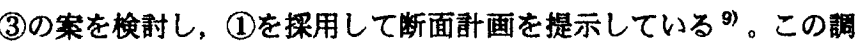
查時にイエメン政府は日本に「ワーディ備」に関する資金援助を 要請している。また䐅れて，「サナア旧市街保全計画」に対する専 門家派遣も要請 ${ }^{10)}$ した。一方で, 同年末に上記 4 案から技術的, 経 済的に可能なオ一プンチャンネル案の採用を決定し，それを监正寨 （イエメン案）としてまとめることにした。当時北朝鮮技術者が保 全事務所に派遣されており，彼らが計画案を作成することになった。

\section{4. 窝施案}

精密測量を䊏え，実測図樎尺 200 分の 1 が作成された後に，設計 は次の 3 段階で進められた。尚，全体計画として檞尺 500 分の 1 の 
完成予想図が途中作成された。各特徽は以下の通りである。

（1)設計第一段階:川床と法面および旧市街内道路交差部を奶象と する雨水・排水計画で, 1989 年 6 月に終了した。

(1)川床(a)楅 : 標準 $9 \mathrm{~m}$ ，部分的に広い简所もある。(b)勾眍 : セン夕 一ラインより両岸へ $3 \%$, 上流より下流へ $2.5 \%$ 。(c)材料 : コンク リートの切石を使用，ただし既存橋下ではコンクリート。

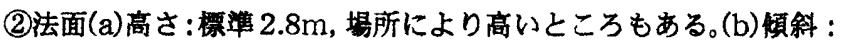
底部は 1:1.25，高部は地形に準ずる。(c)材料：石。

(3)旧市街内道路交差部 : ワーディ東で 7 简所, 西で 6 筒所。

（2）設計第二段階：ワーディを横断する檑の位圈設定とその設計で 90 年始めに終了した。

(1)種類(a)歩車道兼用の橋：1筒所。(b)ハンダック：2箅所, 監視 塔を含む。（c)歩行者尃用の橋： 3 简所。ただし，監視塔付きハン ダックは復原ではなく新しくデザインしている。

(2)位圈(a) シュウーブ通り，幅䄪 $7.5 \mathrm{~m}$ 。(b) 復原に基づく南北市壁 交差部。(c)ワーディの距離を均等した位置で小学校校門付近, 2 简 所のモスクス口付近。

（3）設計第三段階 : 両岸の歩道・付带施設・緑化計画の設計で，完 成予想図には計画されているが，詳細設計は未着手のままである。

(1)歩道 : ワーディ沿いに高さ $80 \mathrm{~cm}$ の胸壁を設置, 朱は石で舖装。

(2)付带施設・緑化 : 店舖の配䁖, ベンチ及び照明器具の設量, 植樹。

\section{5. ワーディ整縞虽の効果}

ワーディ整備事業はサナア旧市街保全計画の重要項目の一つであ り，事業を実施することで旧市街には以下の効果が期待できる ${ }^{11) 。 ~}$ (1)雨水排水機能の完備 : 旧市街における都市排水機能を完全なもの とし，基盤整储を完結できる。

(2)交通整備 : 交通流通譏能が円滑化され，住民の生活に利便性と安 全性を与える。

(3)コミ処理 : 都市廃㹐物の収集機能に役立ち，都市環境を向上させ， 健康的な都市生活を育成できる。景観に調和する緑地計画により新 たな都市景覾の創造に役立ち，都市生活のアメニティを増大させる。 (4)覾光開発 : 観光客の流動を容易かつ多様化することに役立つ。

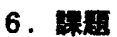

旧市街への効果が期待される一方で課題もある。課題は相互に関 連するが，大きく分けると以下の 4 点をあげることができる。

\section{(1) 都市計画的課題}

(1)ワーディ整備計画の背景には都市住宅省と保全事務所における意 見の食い違いが見られる。道路としての整備と河川としての整備は 開発と保全の問題にも繁がるものである。しかし基本的にはワーデ イの整備はサナア市都市計画の中で位㯰付けられるべきものであり, 整備計画の内容について共同で取り組むべき棵題である。旧市街だ けを対象とした実施案には問題がある。

(2)川の流下能力を考虑し, 上流, 下流では調整池と農慈用水を兼用 した雨水貯留施設の設置を検討することが必要である。土砂が整備 した河床に流れ込まないような制御も求められる。旧市街内を对象 とした実施案では雨期に大量の土砂が流れ込む可能性が高い。

(3)今後首都サナアに人口が集中し, 都市域が桩大すれば道路舗装率 は上がり, 雨水浸透度は限りなくゼロに近づく。大量の表面流が発
生するとともに洪水到達時間も短くなり, ワーディ沿いに水害の危 険を伴う。雨水が浸透しやすい土地の市街化を㧕制する一方で市域 全体の雨水排水計画が必要となる。

(4)歴史的に見ると, ワーディが氾濫する简所は居住地区としての旧 市街部分のみであった。しかし近年の都市化でワーディ上流下流の 両岸に不法占拠的居住区が形成され始め, 洪水汇濫予想区域は㧪大 する傎向にある。洪水の氾濫も「神の思し召し」的に据えられてい るが, 都市防災の注意喚起を促すことが必要となる ${ }^{12) 。 ~}$

\section{(2) 技術的課題}

(1)洪水ピーク流量 $\mathrm{Q}=100 \mathrm{~m} / \mathrm{s}$ が正しいとした埸合 ${ }^{13)}$

計画の修正オープンチャンネル案で $Q=100 \mathrm{~m} / \mathrm{s}$ を流下すること ができるかどうかの検癿をする必要がある。計画断面 $1 ， 2$ の流下 能力はQ $1=126 \mathrm{~m}^{3} / \mathrm{s}, \mathrm{Q} 2=137 \mathrm{~m} / \mathrm{s}$ であり, 流下能力は满たし ているものと考えられる。しかし，安全率などを考慮するならば十 分な断面であるとは言いがたい。

(2)洪水ピーク流量 $\mathrm{Q}=100 \mathrm{~m} / \mathrm{s}$ が正しくないとした場合 ${ }^{14)}$ 本検討で仮定した流城面積, 流出係数等を用いて, 日本で使われて いる合理式により流量を計算すると $\mathrm{Q}=170 \mathrm{~m} / \mathrm{s}$ となり, イタリア 案で报われている洪水ピーク流量 $\mathrm{Q}=100 \mathrm{~m} / \mathrm{s}$ より大きくなる。 る。このため $\mathrm{Q}=100 \mathrm{~m} / \mathrm{s}$ を採用した根拠及び次の項目について調

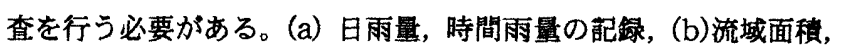
地表状热（荒れ地, 早生, 植林, 植樹, 舖装等)，(c)最上流地点少 らの距離及び標高差, (d)過去のワーディの氾濫状況

尚, $Q=100 \mathrm{~m} / \mathrm{s}$ を確保するためには次のような施設を設けて雨 水の流量をコントロールしなければならない。

（a）洪水が旧市街内に到達する途中に媩整池を設ける。(b)道路の地 下に暗渠を設置して排水し，平時は下水道として利用する。

(3)施工上の課題

(1)技術指導 : ワーディは涸れ川である。雨水は高地から低地へと流 れ，途中で地中に浸透する。途中の貯留水も時間とともに浸透，烝 発する。この钼念の上に「舗装」するという近代的技術が徐入され たため施工の上では常裁である排水用勾配をとることが街路䟣装事 業において無視されてきた。排水洅が設置されることもなかった。 ワーディ俑計画の実施にあたっては施工者への技術指導が必要で ある。指㛵がないままの施工では途中の河床で貯留水ができ，不衛 生な環境をつくることになる。

(2)施工方法 : 備計画はワーディを中心として, 河床, 法面, 両岸 の歩道及び住宅までを石により舗装することになっている。連続し た石舗装により通過車轌からの振動は住宅に伝わる。両岸の住宅間 には上下水道管も埋設されているため振動を制御するための施工方 法が必要となる。旧市街内街路舗装事業により車両通過が堌加し， 塔状住宅にクラックが入った例が多数ある。

(4) 技術協力の課題

(1)専門家の多くは「サナア旧市街保全」を目的に派遗され，業務を 実施しているため，市域全体を通して旧市街を捉えることをしない。 これには各省の事撲指針による影数もあるが，ワーディは道路や河 川として市城全体の中で捉えるべきである。

(2)イタリアは旧市街保全調查において交通計画を考える豚にサナア 市全域を概観して提案を行った。ワーディ整備案もその中に含まれ る。しかし，整備計画案の経緯調査はしておらず，過去の案を誤解 
する結果となった。そしてその後派遣された多くの諸外国専門家は このイタリア報告書から全てを判断することになり，基付け調査が 行われたのものは限られる。徽底した調査が望まれる。

(3)この事業はアメリカ国際開発庁USAIDの資金協力で 1998年に開 始された。しかし同機関は尃門家派遣はしておらず，施工図面を㭘 射することなく事業を進めている。さらに保全事務所は施工業者選

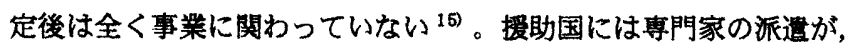
保全事務所には現場責任者・担当者の選任などが求められよう。

\section{7.まとめ}

本稿はサナア旧市街保全計画の一つであるワーディ・サーイラー 整储計画を取りあけ，特に国際協力の立場から事業内容を检致し課 題を明示した。各援助国政府の協力方針の逎いが根底にあるために, 政府間レベルと現場レベルでの理想と現実がかけ離れ，また派遺専 門家と現地保全事務所スタッフ間でも連うことがある。保全事務所 が設立され，旧市街の保全が目指されながらも関保者の共通恋識の 不在が技術協力の現場に与劣影整は大きい。このような状況をど のように調整し，打開策を見つけるかは今後の大きな課題となろう が，本報告では国際技術協力のあり方を考元る㻮の基脴的資料を提 供できたものと考える。

\section{卙群}

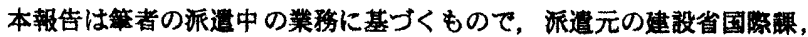
国際势力事業団派遗事業部，さらに派遭先のサナア旧市街保全事務所に感 粨いたします。

注

1) 1990 年 5 月にイエメンは南北統一し，機構改革が行われた。このた 「サナア旧市街保全事務所」は文化・覞光省「歴史的都市保全機構」と 政称された。本稿では当初の名称を用いる。

2）拙㖮：「イエメン・サナアの歴史的環境の保全について 国際協力によ る保全活動の動向」，『日本建策学会計画系論文報告集』第 500 号 pp.185-190 1997.10 に咩しい。

3）策者は国腙協力事業団より1989 年10月〜1992年 2 月まて派薏された。 業務の内容住「サナア旧市街保全計画」に間する助言・指耑である。保 全計画そのものは広籍な内容を含むが，倜々の成保業務を通してカヴ ターパートに技術移転をすることが要門家の基本的な投割である。本報 告は派退初期に関かったワーティ整储計面に関するものて, 以下の2 料（筆者作成報告書）に基づき，実施案作成までを中心に論じている。

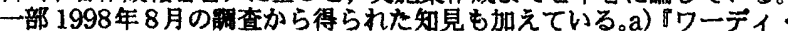

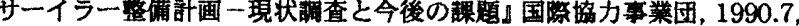
b) Study report on the wadi al-Sa'ilah improvement project, JICA, September, 1990

4) ワーディはアラビア語て，淍れ川を意味する。

5）イエメンは海岸戦争でイラク側についた。このため近隣産油国，特にサ ウデ・アラビアやクェート等に出稼ぎ労做として就当していたイエ メン人はその後強制情国させられた。首都サナアにおいて暗を求めて集 まる引き上け労做者をイエメン政府は一時的にタクシ一運転手として 等湖することを吘可した。このため人口集中とともに引き上け時に持ち

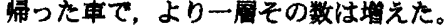

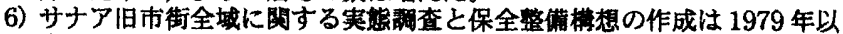
降イタリア政府の䈍暴资金によりイタリアのコンサルタント会社が実

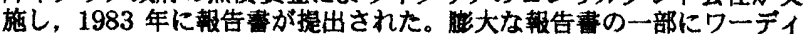

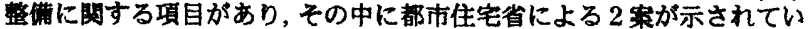
る。 Studio Quaroni S.r.l.: Technical Infrastructure Aspect, General Organization for Antiquities and Libraries, pp.25-29, 1983

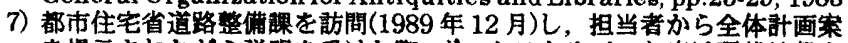
を提示されながら説明を受けた祭，ボックスカルバート案は現状地盤を 若干留えながらも川床下に圈かれていることが判明した。これ以後の保 全事務所に派遭された諸外国尃門家はイタリア・コンサルタントの報告 書をそのまま利用した。このような背景か54実の一つとした。

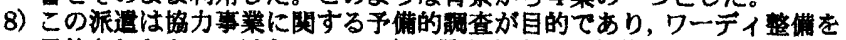
目的亡したものてはない。この腺は保全事拸所の会議において提示され た。石井昭：『䋛合報告書》 p.4,p.108，国際協力事業团 1987.12

9) Ministry of Construction + International engineering consultants association: Preliminary study report on the improvement for the Wadi Sa'ilah in the Old City of Sana'a, pp.16-17, p.30, 1989

10) 1989 年 10 月にJICA は「サナア旧市街保全計画」の技術指望として短 期, 長期の 2 名の尃門家を派㟟した。この 2 名はワーティ整满事業が日
本政府の無供算金拨助の候補であることを事前に知り，派遗前にアイデ

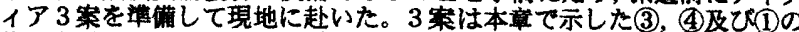
集正察(これは中央にオープントレン于を設け，年間を通して流水を残 そうというもの) である. (Akira Ishii+ Masaji Yoshida, Basic Ideas for Solution of Vehicle Traffic, Rainw ater Drainage and Landscape Problems, 1989）しかしイエメン㑡はこれら事前涪储の案が提示され る前にすでに実施案を決めていたので本稿では省いた。1990 年 4 月に

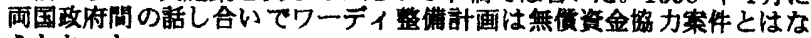
らなかった。

11) Ministry of Construction, op.cit.,pp.33-35

12）8月怡雨期にあたるが, 1998 年は例年と遣い約 1 调間以上も雨が続き, 異常気象といわれた。雨が降るのは1日のう方数時間であるが、ワー宁 1は増水し最高 $1 \mathrm{~m}$ に遠した。(日中水位は40cm 以下になる。)この ためこの期間に死者，行方不明者が 10 数名出たと言われる。

13）本稿は土木工学的知見を要しないが，技術的検时を試みる。 标淮断面を 2 例を取りありて部画断面の检砷を行う。 流下量 $\mathrm{Q}=\mathrm{A} \mathrm{v} \quad\left[\mathrm{A}\right.$ : 断面楼 $\mathrm{m}^{2}, \mathrm{v}$ : 平均流速 $]$ 平均流速 $\mathrm{v}=1 / \mathrm{n} \times \mathrm{R}^{2 / 3} \times \mathrm{I}^{1 / 2} \quad[\mathrm{n}:$ Manning $の$ 粗度保数, $\mathrm{I}$ : 底勾配] $\mathrm{n}:$ ライニング水路では 0.025 , $\mathrm{I}=(47.18-43.19) \quad / 1355=0.003, \quad \mathrm{I}^{1 / 2}=0.055$

例 2

断面積 $\mathrm{A}=36.96 \mathrm{~m}^{2}$, 淍辺 $\mathrm{S}=19.08 \mathrm{~A}=36.71 \mathrm{~m}^{2}, \mathrm{~S}=16.52$ 径深 $\mathrm{R}=1.94, \quad \mathrm{R}^{2 / 3}=1.55 \quad \mathrm{R}=2.22, \mathrm{R}^{2 / 3}=1.70$ 故にQ=126.03 m/s $\quad Q=137.03 \mathrm{~m} / \mathrm{s}$ となる。以上より,この計画断面では $Q=100 \mathrm{~m} / \mathrm{s}$ を流下させることが できる。
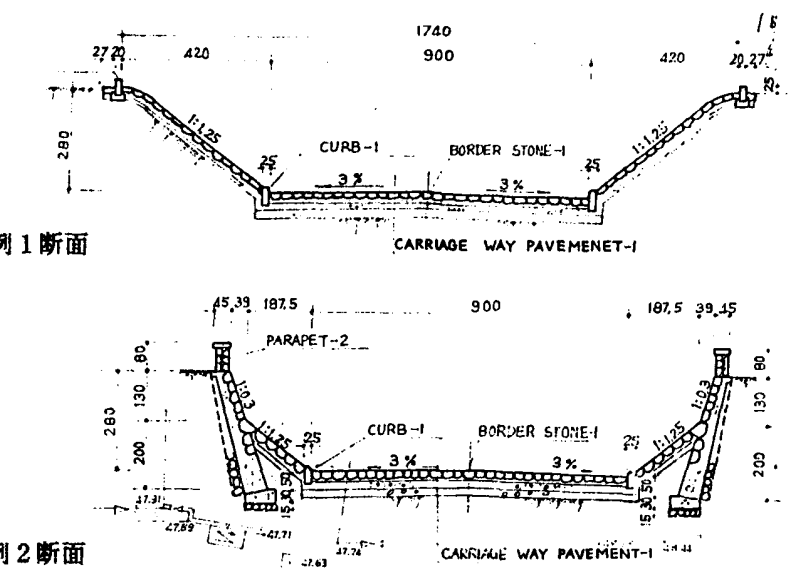

例 2 断面

14）イタリア案て报われている洪水ピーク流量 $100 \mathrm{~m} / \mathrm{s}$ やイエメン苯での

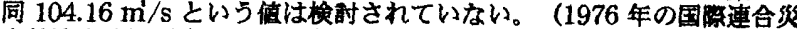
害救济事務局が降水量を調查した記踏があるが内容恃不明でる。の 報告書を参孝にしてイギリスのコンサルタントは2000年におけるワー ティ下流 $9 \mathrm{~km}$ 地点での洪水ピーク流量を $104.16 \mathrm{~m} / \mathrm{s}$ と推算してい る。）そこで式みに日本士木学会の水理公式集を参将にし，次の合理式 を用いて洪水量の推定を行う。

$\mathrm{Qp}=1 / 3.6 \times \mathrm{fp} \times r \times \mathrm{A}$ [Qp : 洪水ピ一ク流量 $\mathrm{m} / \mathrm{s}$ ， fp:ピーク 流出保数 $(0.45 \sim 0.75) ， r$ : 洪水到達時間内の平均有奻降雨強度 $\mathrm{mm} / \mathrm{hr}, \mathrm{A}$ : 流城面稓 $\mathrm{im}$ ]

また, To : 洪水到達時間 $\mathrm{s}($ Kraven の表による推定 $\mathrm{T} p=\mathrm{L} / \mathrm{W}) ， \mathrm{~S}$ ： 流炉勾配，W : 洪水到達速度 $\mathrm{m} / \mathrm{s}, \mathrm{L}$ : 流路長 m

$こ こ て, A=100 \mathrm{~km}, L=12 \mathrm{~km}, \mathrm{fp}=0.5, W=2.1 \mathrm{~m} / \mathrm{s}$ とし,

$r=48 \mathrm{~mm}$ (1980 年以降の最高記䟿は $43.1 \mathrm{~mm}-85$ 年 5 月) とすれ K $\mathrm{Tp}=12,000 / 2.1=5,714.29 \mathrm{~s}=1.59 \mathrm{hr}$

$r=48 / 24(24 / 1.59)^{2 / 3}=12.22 \mathrm{~mm} / \mathrm{hr}$

故にQ $\mathrm{Q}=1 / 3.6 \times 0.5 \times 12.22 \times 100=169.72 \mathrm{~m} / \mathrm{s}$

この結果，Qは実施案に採用した值の約 1.7 倍となりワーティは洪水を 起こすことになる。

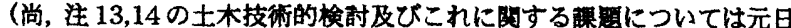
本シールドエンジニアリング株式会社企画䩗查室久保田真氏からご 示原いた。ここに即して腤意を表したい。)

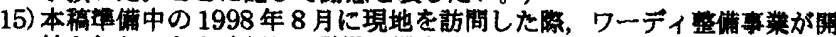
始されたことを確認し，現場を視察した。この時以下の点が確㒛できた (1)旧市街のみが擎備事業の対象となっている。(2)ワーティ全体に勾的が 取られていない（図面通りの施工でない）ために水が質留する簿所がて きた。(3)左岸，右岸耐牌の住宅間が赤装され車博通過時にこれまで以上 に住宅に振勳が伝わる。(4)上流に哃整池が整储されていないために，洪 水流出時に大量の土砂が流れ込み排水後に土砂が堆稹した。上法繁者

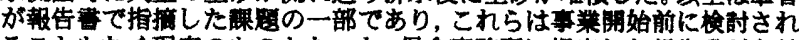
ることもなく現実のものとなった。保全事務所に提出した赤告書が有効 に利用されないところにも国际協力の輩题はあるように思われるが，全 体的に見て保全という名目上に成り立つ授助国，あるい保全事務所の 自己满足の協力・体制の姿となったとい方るのではないか。

[1998年10月20日原稿受理 1999年 2 月 8 日採用決定］ 